\title{
HERMENEUTYKA HISTORII W ASPEKCIE PRAWDY ROZUMIENIA
}

\section{PROBLEM DOSWIADCZENIA HISTORII}

Problem historii posiada szczególne znaczenie w kontekście hermeneutycznym. Odnosi się to nie tylko do tekstów ściśle historycznych, ale do każdego tekstu językowego, który chce się właściwie rozumieć. Każde zatem rozumienie tekstu językowego winno zakładać i uwzględniać jego historyczny wymiar. Co więcej, samo rozumienie odznacza się historycznością, gdyż jako poznanie hermeneutyçzne dokonuje się w horyzoncie czasu. Jeżeli rozumienie ma być najbardziej adekwatnym aktem naszego poznania, to musi ono uwzględnić całą rzeczywistość języka, w tym również to, co stanowi jego aspekt historyczny. Może się wydawać, że problem czasowości i historyczności tekstu językowego, powinien stanowić przedmiot zainteresowań i badań historyka. To historykowi chodzi o badanie przeszłości, jej rozumienie i ujęcie prawdziwego jej znaczenia. Jednak trafnym wydaje się być stwierdzenie Droysena, który dostrzega złożoność problemu doświadczenia i rozumienia historii. „Nie ma przeszłości, która w całej rozciągłości byłaby już rozumiana, jako że posiadamy tylko zawężone, częściowe i dość niejasne wyobrażenie o faktach przeszłości"1.

Tym, co jest ważne w podejmowaniu problemu doświadczenia historii na gruncie języka, to uznanie dynamicznego charakteru jej rozumienia. Rozumienie, jako akt doświadczenia i poznania, może być stale dopełniane, poszerzane i stale na nowo interpretowane. W takim przypadku trudno byłoby twierdzić, że rozumienie jest prostym ujmowaniem sensu. Należy raczej uznać, iż rozumienie historyczne jest procesem analizy i syntezy równocześnie oraz jest rezultatem indukcji i dedukcji naszego poznania rozumowego. Nie ulega wątpliwości, iż zagadnienie rozumienia historycznego na gruncie językowym, zawiera wiele spraw kontrowersyjnych i dotąd jeszcze nie wyjaśnionych. Do takich zagadnień należy zaliczyć samo pojęcie historii oraz jej możliwość doświadczenia na drodze hermeneutycznej. Funkcja dystansu czasowego i możliwość tylko pośredniego doświadczania faktów historycznych. W końcu, historyczny charakter rozumienia oraz zagadnienie jego prawdziwości, a więc problem prawdy hermeneutycznej.

1 J.G. Droys e n, Historik, München 1943, s. 12. 


\section{Hermeneutyczne określenie historii}

Kontrowersje, jakie powstają, odnoszą się do samego pojmowania historii i do jej zakresu. Droysen określa historię, jako „ogól przedstawiających się nam zjawisk stawania się i postępu" ${ }^{2}$. Takie określenie historii wydaje się być o tyle trafne, że obejmuje swoim zakresem rozwój i postęp w świecie zjawisk i rzeczy, ale także całą dziedzinę życia duchowego, a więc moralnego i umysłowego. Oprócz tego, Droysen akcentuje dynamiczny charakter rzeczywistości historycznej. Należy jednak uściślić ten bardzo szeroki zakres pojęcia historii i ograniczyć go do pewnego zakresu. Zakres ten, wyznacza obecność człowieka, gdyż o historii możemy mówić tylko tam, gdzie istnieje świat człowieka, który przenikany jest przez jego świadomość. Poza tym zakresem znajduje się, tym samym, świat natury czystej i świat nadprzyrodzony, czlowiek bowiem nie jest zdolny ująć tego świata w właściwe kategorie świadomości. Człowiek jako istota cielesno-duchowa partycypuje w obu tych zakresach i dzięki temu możliwe jest ciągłe tworzenie i przekształcanie form poznawczych. Procesowi poznania towarzyszy zawsze proporcjonalna świadomość rozumienia. W tym sensie zakres działania i poznania ludzkiego będzie wyznacznikiem zakresu historii i stanowi kryterium jej rozumienia.

\section{Historyczność a dziejowość}

Hermeneutyka nie może nie podjąć tego, co stanowi wymiar czasu, a co w głównej mierze stanowi przeszłość ludzkiego działania. Celowym jednak będzie przeprowadzić wyraźne rozgraniczenie pomiędzy tym, co określane jest mianem historii, od tego, co stanowi o dziejach i dziejowości. Potoczne rozumienie dziejowości łączy się najczęściej z faktami, które należą do przeszłości oraz z tymi, które wprawdzie są obecne w teraźniejszości, ale nie mają na nie zasadniczego wpływu. Historyczność natomiast obejmuje to wszystko, co już przeminęło i właśnie jako takie posiada i wywiera swój istotny wpływ na doświadczenie i rozumienie wszystkiego, co jest urzeczywistniane w teraźniejszości. Tak więc, w przypadku dziejowości, mamy do czynienia z faktami przeszłości, które charakteryzuje niepowtarzalność, zaś historyczność, choć związana z przeszłością, aktualnie kształtuje nasze rozumienie teraźniejszości i przyszłości. Martin Heidegger, próbując określić trójwymiarowość historii, posługuje się określeniem e p o ch é, które ujmuje w całość czasową przeszłość, teraźniejszość i przyszłość. Należy przy tym zaznaczyć, że dla Heideggera wymiar przeszłościowy nie posiada uprzywilejowanej roli. Pochodzi to z założeń ontologicznych, gdyż zdaniem Heideggera, dziedzina historii nie stanowi odrębnego zakresu bytowego, który należałoby oddzielić i odróż-

\footnotetext{
${ }^{2}$ Tamże, s. 12.
} 
nić od natury egzystencji bytu ludzkiego. Przeciwnie, historia jest specyficznym wydarzeniem bytu ludzkiego, który daje się nam w czasie, stając się wydarzeniem należącym do przeszłości i działającym w stronę przyszłości.

\section{Antropocentryczny charakter historii}

Obecność człowieka i jego świadomości jest tym czynnikiem, który wiąże wydarzenia dziejowości świata w całość oraz decyduje o tym, że stają się one przedmiotem poznania i rozumienia. To ścisłe uzależnienie poszczególnych faktów dziejowości od człowieka, jako bytu poznającego, prowadzi w konsekwencji do stwierdzenia, iż są one konstytuowane pod względem ontologicznym przez człowieka. Skąd pochodzi ta uprzywilejowana pozycja człowieka w czasie i w historii? Otóż, o człowieku mówi się, że w sposób najbardziej właściwy przysługuje mu historyczność; wtórnie historycznymi są wszystkie byty świata. ${ }^{3}$ Wiadomo już, że potoczne rozumienie historii ogranicza się do jej wtórnego charakteru, a więc do bytów należących do horyzontu ontycznego świata. Tym, co konstytuuje byt ludzki w jego historyczności jest przede wszystkim jego specyficzny charakter egzystencji, która cechuje się celowością i przeznaczeniem. Oczywiście swój ciężar istotowy celowość zyskuje przez określoną przyszłość. W przypadku człowieka, możemy powiedzieć za Heideggerem, jest to jego bycie-ku-śmierci ${ }^{4}$. Byt ludzki charakteryzuje się czasowością i dziejowością, ale tym, co jest najbardziej właściwe i charakterystyczne dla człowieka, to posiadanie historyczności. Mówiąc o dziejowości świata, należy rozróżnić jego podwójne znaczenie: jako zespół bytów istniejących w świecie oraz jako bytów związanych i uświadomionych przez podmiot poznający. Ten związek bytu ludzkiego ze światem okazuje się być czymś koniecznym, jeżeli chcemy mówić o historii i rozumieniu świata. Transcendencja bytu ludzkiego suponuje zarówno dziejowość świata, jak dziejowość własnego bytu. Z podłoża tej dziejowości wyrasta historia. Horyzont dziejowości stanowi źródło pytań człowieka, głównie o istniejące związki między bytem ludzkim a bytami świata. Można nawet zaryzykować, idąc za Heideggerem, stwierdzenie, że historia każdorazowo jest zależna od „poglądu człowieka na świat” i jako taka ma swoje zakorzenienie na gruncie ontycznym historii bytu ludzkiego. Można zatem skonstatować, że egzystencjalnym źródłem historii jest przede wszystkim dziejowość i historyczność człowieka ${ }^{5}$. Istotną funkcję człowieka w horyzoncie dziejowości stanowi językowa tematyzacja wydarzeń. Tematyzacja staje się możliwa tylko wtedy, gdy przeszłość została w jakiś sposób otwarta dla czło-

\footnotetext{
${ }^{3}$ Por. M. Hei de g ge r, Sein und Zeit, Halle 1941, s. 381

${ }^{4}$ Por. tamże, s. 386.

5 Por. tamżc, s. 392.
} 
wieka. „Otwartośc”, według Heideggera, warunkowana jest przede wszystkim obecnością człowieka.

\section{Powszechność tematyzacji historycznej}

Uzależnienie historii od bytu ludzkiego oraz jego obecności w horyzoncie dziejowym świata, może sugerować niebezpieczeństwo partykularyzacji. Obecność czasowa i przestrzenna człowieka, która pozostaje z konieczności, ograniczona do części świata, nie stanowi jeszcze istotnej trudności w całościowym ujmowaniu tego, co minęło, po czym pozostały tylko ślady. Możliwość wyjścia poza partykularyzm historyczny, stwarza historia własnej dziejowości - dziejowości bytu ludzkiego, która w każdym momencie dziejów świata stanowi i tworzy swoistą „ogólność”. Stąd też, historia, która stanowi przedmiot hermeneutycznego rozumienia, nie zostaje sprowadzona do pojedynczych faktów, ani też do zachodzących w niej prawidłowości, ale jest wyznaczana przez każdorazowo i „faktycznie istniejącą możliwość”6. „Możliwość” opiera się na egzystencji i pozostaje ukierunkowana na fakty, co sprawia, że nasze rozumienie historii nie zatrzymuje się na sensie poszczególnych faktów dziejowości, ale przenika do tego, co w nich jest faktycznie obecne i co wskazuje na to, co powszechne. Tak więc „możliwość” wyznacza pierwszorzędny przedmiot rozumieniu hermeneutycznemu historii. Drugorzędnym przedmiotem historii jest czasowość bytu, która pozostaje w ścisłym związku z sensem egzystencjalnym bytu i z jego tro s ką7. „Troska będzie więc stanowić przedmiot tematyzacji historycznej. Wynika to stąd, że stanowi ona element strukturowy bytu ludzkiego, ona również ukazuje jednoznacznie jego czasowość, przemijanie i jest wyznacznikiem swoistego zatroskania o przyszłość. Zarówno możli wo ść, jak i t ro s k a będą wyznacznikami dla tworzenia historii powszechnej, one też powinny wyznaczać kryteria rozumienia hermeneutycznego historii. Praca historyka, jeżeli ma zmierzać do coraz pełniejszego rozumienia, nie może ograniczyć się do zbierania faktów przeszłości i nie może być, jak mówi Pannenberg „pracą ogrodnika cmentarnego". Tym, co należy uwzględnić w rozumieniu historycznym, jest poszukiwanie zbieżności z teraźniejszością. Wyrazem tych poszukiwań będą pytania, jakie każdorazowo historyk-interpretator stawia historii. Specyfika interpretacji historycznej polega na próbie dotarcia do źródła historycznego oraz na dążeniu do zrozumienia autora w horyzoncie jego własnego czasu ${ }^{8}$. Ażeby nie zawężać przedmiotu rozumienia historii, należy w doświadczeniu historycznym objąć to, co materialne i co duchowe. Można nawet

${ }^{6}$ Tamże, s. 394.

${ }^{7}$ Por. tamże, s. 397.

${ }^{8} \mathrm{~W}$. Pann en berg, Hermeneutik und Universalgeschichte, „Zeitschrift für Theologie und Kirche" 60:1963 s. 92. 
mówić o świeckim i religijnym przedmiocie historii. W każdym razie chodzi o „sensowne wyprowadzenie i ustalenie właściwej zależności wydarzeń historii, w której poszczególne fakty otoczone byłyby pewnym sensem czy nawet duchowością" ". Powszechność rozumienia historycznego implikuje apriorystyczną i teleologiczną interpretację faktów, jeżeli chcemy zmierzać do uniwersalistycznej koncepcji historii. Ten uniwersalizm rozumienia hermeneutycznego historii pozwala doświadczyć owej „niewidzialnej duchowości, która urzeczywistnia się w konkretnych przedmiotach $i$ wydarzeniach stwarzając w ich zakresie odpowiednią sferę możliwości"10. Sfera możliwości, przy właściwym wnioskowaniu i abstrahowaniu, pozwala nam przejść od jednostkowych i szczegółowych doświadczeń historycznych do całościowego ujęcia i rozumienia sensu. Całościowy horyzont rozumienia sensu pozwala z kolei ująć i rozumieć poszczególne wydarzenia historii. Właściwie każdy tekst historyczny implikuje to, co wykracza poza każdorazową sytuację historyczną i odnosi do tego, co stanowi o uniwersalistycznym charakterze historii.

\section{Horyzont hermeneutyczny historii}

Aspekt hermeneutyczny tekstu historycznego powinien umożliwić wyjście z kręgu faktów jednostkowych i ich rozumienia ku całościowemu i pełnemu rozumieniu. Określone miejsce w horyzoncie hermeneutycznym przysługuje historykowi - interpretatorowi, który $\mathrm{m}$. in. ma za zadanie odróżnienie i oddzielenie nakładających się na siebie horyzontów: teraźniejszości i przyszłoś$\mathrm{ci}^{11}$. Hermeneutyczny horyzont historii uniwersalnej, formułuje postulat wyjścia poza wszelkie ograniczenia egzystencjalne. Jak się okazuje, analizy egzystencjalne uniemożliwiają właściwe rozumienie złożoności historii, ograniczając się do tego, co właściwe lub też niewłaściwe dla egzystencji ludzkiej. Uniwersalizm horyzontu historycznego ma na celu całościowe ujęcie przeszłości a poza tym stanowi on pewną ideę regulatywną dla wysiłków historyka, który poprzez rozumienie chce dojść do syntezy historii. Horyzont rozumienia umożliwia pewną syntezę we właściwych granicach i przy zachowaniu właściwego kryterium porządkującego fakty ${ }^{12}$. Całościowa wizja przeszłości musi zakładać i uwzględniać jej dynamiczny i nieskończony charakter. Utworzenie siatki powiązań przyczynowych powinno stwarzać perspektywę całości. Określenie miejsca i roli podmiotu w tworzeniu horyzontu hermeneutycznego ma za zadanie doprowadzić do obiektywnego rozumienia historii. Ricoeur, mówiąc o obiektywności rozumienia, odwołuje się do znanych skądinąd kryteriów, iż

\footnotetext{
${ }^{9}$ A. P a u s, Religiöser Erkenntnisgrund, Leiden 1966, s. 175.

${ }^{10}$ Por. tamże, s. 176.

${ }^{11}$ W. Dilt he y, Gesammelte Schriften, Stuttgart 1958, s. 102.

12 Por. P. Ri icoe u r, Geschichte und Wahrheit, München 1975, s. 44.
} 
obiektywnym będzie to, „co jest wypracowane w metodycznym myśleniu, co jest uporządkowane i co jest pojmowalne"13. Tego typu obiektywizm odnosi się zarówno do nauk przyrodniczych, jak i do nauk humanistycznych, a więc historycznych. Dotychczas trudno jest jednoznacznie ustalić, czym różnią się fakty nauk przyrodniczych od faktów historycznych, ale bezspornym pozostaje, iż fakty przyrodnicze ujmowane są i rozumiane tylko w kontekście historycznym $^{14}$.

\section{Horyzont podmiotowy rozumienia}

W procesie rozumienia hermeneutycznego historii, podmiot przede wszystkim wyznacza i określa celowość analizy tekstów językowych. Powstaje pytanie, w jakim stopniu rola podmiotu może wpływać i w jaki sposób, na obiektywność rozumienia? Właściwym określeniem roli podmiotu w rozumieniu historii jest Kantowskie rozumienie tzw. „przewrotu kopernikańskiego”, w wyniku którego konieczną jest rzeczą uwzględnienie uwarunkowań hermeneutycznych samego podmiotu. Do tych uwarunkowań zalicza się w pierwszym rzędzie sam „wybór historyczny”. Chodzi raczej o dokonanie odpowiedniego doboru wydarzeń i ułożenie ich w pewien ciąg interpretacyjny. Drugą, równie ważną czynnością podmiotu, jest wyjaśnianie faktów poprzez porządkowanie przyczyn i motywów. Czynność ta musi poprzedzać samą refleksję nad historią i jej rozumieniem. Czynnikiem decydującym o obiektywizmie rozumienia tekstu językowego, będzie przyjęcie właściwego dystansu czasowego. W dużej mierze dystans taki uzyskuje się przez język, który dysponuje odpowiednimi terminami przy opisywaniu faktu historycznego i przeprowadzeniu aktualnej interpretacji. Zdaniem Ricoeura, tym co decyduje o obiektywności rozumienia historii, będzie zawsze jej antropocentryczny charakter. Kryterium takie wyznacza samo miejsce w nurcie wydarzeń historii, w którym znajduje się historyk, głównie dlatego, że pozostaje on stale cząstką tej samej ludzkości, która tworzyła poprzednie etapy historii. Można więc, idąc za Ricoeurem, sformułować twierdzenie, iż „obiektywność historyczna jest korelatem historycznej subiektywności"15. Ścisła zależność pomiędzy rozumieniem historii a historykiem jest tak wielka, że „historia tworzy historyka nie mniej, niż historyk tworzy historię"16.

13 Tamże, s. 40.

${ }_{14}$ Por. G. Con quil he m, Etudes d'histoire et de philosophie de sciences, Paris 1968, s. 93 n.

15 Tamże, s. 50.

16 Tamże, s. 52. 


\section{HISTORYCZNOSĆ JAKO ZASADA HERMENEUTYCZNA}

Problem rozumienia historycznego pojawia się z całą wyrazistością w kontekście zagadnień hermeneutycznych. Należy przede wszystkim ustalić czy sama historyczność jest tylko zasadą rozumienia czy też stanowi istotną regułę hermeneutyczną, bez której rozumienie tekstu językowego historii jest wprost niemożliwe. Zagadnienia te są przedmiotem rozważań zarówno na terenie hermeneutyki egzystencjalno-fenomenologicznej, jak i hermeneutyki transcendentalistycznej.

\section{Kontrowersje ontologiczne}

Trudno byłoby pominąć wymiar czasowy w każdym rozumieniu ludzkim i wprost niemożliwym, sprowadzić całość rozumienia do aktualnego horyzontu czasowego. Swoiste stanowisko w tym względzie zajmuje Martin Heidegger, który uważa, iż historia, jako taka, nie wchodzi w ogóle w grę, gdyż nie istnieje. Jeżeli nawet mówimy o wymiarze czasowym w hermeneutyce, to decyduje o tym tylko dziejowość bycia, która się nam ujawnia w swej „nieskrytości” i „otwartości”. Należy jednak podkreślić, iż Heideggerowska koncepcja dziejowości bycia prowadzi w konsekwencji do ograniczeń ontologicznych, co nie jest bez znaczenia dla doświadczenia hermeneutycznego. Wobec stanowiska Heideggera w zdecydowanej opozycji pozostaje hermeneutyka Gademerowska. Gadamerowi chodzi o stworzenie takiej teorii hermeneutycznej, która pozostałaby „wolna od ograniczeń ontologicznych w ujmowaniu rzeczywistości i która usprawiedliwiałaby historyczność naszego rozumienia”" ${ }^{17}$. Pojęcie „kręgu hermeneutycznego" spotykamy już u Heideggera. Spełnia on tam funkcję reguły hermeneutycznej, której celem jest umożliwienie najbardziej pierwotnego poznania poprzez interpretację. Hans Gadamer przyjął „krąg”, ale głównie po to, by zapobiec nadmiernej spontaniczności i dowolności w interpretacjach hermeneutycznych oraz aby uniknąć tych wszystkich ograniczeń, jakie powodują nasze nieuświadomione przyzwyczajenia myślowe. „Krąg hermeneutyczny” Gadamera ma umożliwić dokonanie „asymilacji znaczeniowej własnych uwarunkowań i uprzednich osądów oraz danych wydarzeń i faktów"18. Nie ulega wątpliwości, że w hermeneutyce historii należy uwzględnić i określić stosunek, jaki zachodzi między stale żywą tradycją a jej tematyzacją językową w historii. Gadamer postuluje, aby rozumienia historii nie ograniczać do uwarunkowań podmiotowych i przedmiotowych tekstu językowego, lecz aby uwzględnić tradycję, która spełnia funkcję pośrednika przeszłości. Poza tym

${ }^{17}$ H.G. G a d a me r, Wahrheit und Methode, Tübingen 1961, s. 250.

${ }^{18}$ Tamże, s. 253. 
tradycja wiąże się ściśle $\mathrm{z}$ wymiarem czasowym rozumienia hermeneutycznego. Każda partycypacja w sensie przeszłości stanowi element tradycji i jako taki, wchodzi w każdy akt naszego rozumienia. Tradycja okazuje się być najbardziej odpowiednim narzędziem służącym do ujmowania tego, co znajduje się po mi ę dzy tym, co odległe czasowo, a tym co aktualne w rozumieniu ${ }^{19}$.

\section{Założenia transcendentalne}

Przez długi czas uważano, iż rozumienie należy traktować jako reprodukcję myśli autora i to bez uwzględnienia dystansu czasowego. Dystans jednak jest czymś istotnym zwłaszcza dla rozumienia historycznego, gdyż dzięki niemu możemy autora tekstu ,inaczej rozumieć, jeżeli się go w ogóle rozumie"20. Tak więc problem dystansu czasowego był trudnym do rozwiązania również na gruncie hermeneutyki. Pierwszym krokiem było uznanie Heideggerowskiego „kręgu” i przyjęcie właściwej interpretacji ontologicznej bytu ludzkiego. W miarę postępu, czas przestał być elementem, który oddziela interpretatora od wydarzenia historycznego. Odtąd czas stanowi grunt, w którym bardzo mocno zakorzenione jest rozumienie teraźniejszości.

Stanowisko hermeneutyki transcendentalnej jest najbardziej reprezentatywne i wydaje się najgłębiej uzasadnione w tym względzie. Wymiar czasowy i historyczny stanowi ważną zasadę hermeneutyczną, ponieważ uwzględnia „połączenie fenomenu osobowego (podmiotowego) i rozumienia historycznego i rozpatruje je, jako swoistą całość"21. Uzasadnieniem dla takiego stanowiska jest jednostkowy i społeczny charakter rozumienia historycznego. Jednostka włączona w nurt historii stanowi zamkniętą całość, do której zasadniczo nie mamy dostępu. Fakt ten może w dużej mierze decydować o charakterze naszego rozumienia. W odniesieniu do rozumienia historycznego byłoby to równoznaczne z ograniczeniem, a nawet zniesieniem tego rozumienia. Sprowadzanie rozumienia historycznego do uwarunkowań czasowych stwarza pewne niebezpieczeństwo, gdyż każdy łańcuch przyczynowy odsuwa na dalszy plan sam fenomen historyczności, który w efekcie pozostaje niezrozumiały w swoim sensie. Hermeneutyka natomiast powinna oprócz uwarunkowań czysto zewnętrznych, uwzględnić uwarunkowania duchowe, które są bliższe człowiekowi. Można nawet mówić o wspólnej dla wszystkich ludzi płaszczyźnie doświadczeń, ocen i celów. Zdaniem Coretha płaszczyzna ta „stanowi warunek umożliwiający osobowe rozumienie historii. Na tej podstawie możemy rozumieć odrębność światów historycznych"21.

19 Tamże, s. 279.

20 Tamże, s. 280.

${ }^{21}$ E. Cor eth, Grundfragen der Hermeneutik, Freiburg 1969, s: 122. 


\section{Czasowość jako zasada}

Hermeneutyka w swoich założeniach nie może poprzestać i zadowolić się częściowym rozumieniem. O coraz pełniejszym rozumieniu tekstu językowego historii w dużej mierze ma decydować reguła hermeneutyczna cza s o w oś ci. Jej działanie najbardziej jest widoczne w dynamicznym rozwoju wszelkich niuansów znaczeniowych i treściowych historii. W rozwoju historycznym „otwierają się coraz to nowe treści sensu i uwarunkowań, które nie były nawet znane samemu autorowi tekstu historycznego" 22 . Reguła „czasowości” pozwala na uwzględnianie stale nowych sytuacji, które umożliwiają stawianie nowych pytań i szukanie na nie pełniejszych odpowiedzi. Hermeneutyka transcendentalna wprowadziła istotne rozróżnienie pomiędzy rozumieniem historii a rozumieniem w historii. W pierwszym przypadku chodzi o ujmowanie sensu obiektywnych stosunków, w drugim o podmiotowe ujmowanie sensu poszczególnych wydarzeń dokonujących się w historii ${ }^{23}$. Skoro źródłem sensu w tekstach historycznych nie jest opisywany fakt, ale (również) stosunek poznawczy historyka, to dystans czasowy wnosi do rozumienia tego sensu cały egzystencjalnodziejowy wymiar bytu ludzkiego. W konkluzji możemy stwierdzić, iż czasowość pozostaje nieodłącznym elementem każdej sytuacji hermeneutycznej. Nie może być pominięta jako zasada rozumienia historycznego. Stanowi ona postulat otwartości ludzkiego bycia, które w swoim dynamizmie prowadzi ku pełni i prawdzie poznania hermeneutycznego historii.

\section{PRAWDA ROZUMIENIA HISTORYCZNEGO}

Historyczność, jako reguła hermeneutyczna, prowadzi do rozumienia sensu historii. Równocześnie postulatem poznawczym staje się dążenie do praw dzi o ości tego rozumienia. Słuszną jest więc rzeczą mówić o prawdzie historycznej, która pozostaje w bezpośrednim związku z historycznym wymiarem rozumienia hermeneutycznego.

\section{Prawdziwościowa funkcja człowieka}

Byt ludzki znajduje w świecie swoje miejsce, dzięki czemu uwikłany jest w każde zróżnicowanie i historyczność. Ażeby dojść do prawdy rozumienia tej sytuacji należy wkroczyć na drogę interpretacji transcendentalno-metafizycznej. Chodzi w pierwszym rzędzie o połączenie tego, co określa się mianem „physis”, z jej stroną formalnej interpretacji, a więc „logosem” w jedną całość

22 Tamże, s. 137.

${ }^{23}$ Por. tamże, s. 138 n. 
„auton”, która ostatecznie stanowi jedność bytu i myśli24 . Zakładając antropocentryczny charakter rozumienia hermeneutycznego, tym samym implikujemy antropologiczny wymiar jego prawdy. Potwierdzeniem tego jest stanowisko Lotza w tym względzie. Swiat bez człowieka przestałby być miejscem prawdy, natomiast człowiek pozbawiony prawdy swego rozumienia, nie byłby już tym czym jest. Historyczność człowieka „nie tylko zakłada możliwość istnienia prawdy, ale wprost musi ją zawierać" 25 . W przypadku hermeneutycznego rozumienia historii ważną będzie prawda poznania historii. Każde ograniczenie horyzontu poznawczego w sferze uwarunkowań historycznych, prowadzić będzie do eliminowania pełnej i absolutnej prawdy naszego poznania. Prawda poznania historycznego konstytuowana jest zarówno przez podmiot poznający jak i przez czynniki obiektywne. Uwarunkowania prawdy historycznej nie wykluczają możliwości istnienia na gruncie hermeneutycznym prawdy ponadhistorycznej, tzn. prawdy, która pozostaje absolutnie ważną. Zgodnie z założeniami interpretacyjnymi bytu ludzkiego, który pozostając w horyzoncie świata równocześnie transcenduje w kierunku absolutu, prawda historyczna i ponadhistoryczna wzajemnie do siebie należą. Prawda ponadhistoryczna suponuje istnienie prawdy historycznej. Transcendujące poznanie ukazuje nam prawdę historyczną na coraz wyższych stopniach rozwoju. Zdaniem Lotza „prawda historyczna dzieje się niejako przez człowieka, ale prawda ponadhistoryczna może być dziełem Boga"26. Spośród wielorakich uwarunkowań prawdy historycznej hermeneutyka wyodrębnia uwarunkowania językowe. W odniesieniu do tekstów językowych historii najlepiej widać rolę pośredniczenia, jaką spełnia język. Odnosi się to nie tylko do rozumienia, ale również do prawdy tego rozumienia. O języku mówi się, że jest „mieszkaniem prawdy”, ponieważ zawiera ją w sobie. Tylko w akcie rozumienia prawda języka jest nam dana i to w zależności od stopnia rozumienia określić możemy stopień prawdy ${ }^{27}$.

\section{Prawda doświadczenia hermeneutycznego historii}

Podobnie, jak nie można bezkarnie oddzielać rozumienia historii od doświadczenia języka historii, tak samo prawda tego rozumienia pozostaje złączona $\mathrm{z}$ językiem historii. Każde słowo wypowiedziane $\mathrm{w}$ historii znajduje w niej swoje urzeczywistnienie. Nasze poszukiwania prawdy historii muszą wziąć pod uwagę całą złożoność struktury hermeneutycznej języka. Fakt przynależności prawdy do języka historii stanowi zasadniczą regułę hermeneutyczną. Poza tym sens historii posiada charakter egzystencjalny, tzn. związany po-

\footnotetext{
${ }^{24} \mathrm{~F}$. Wi plinge r, Wahrheit und Geschichtlichkeit, Freiburg 1961, s. 349.

25 J-B. Lotz, Von der Geschichtlichkeit der Wahrheit, „Scholastik” 27; 1952 s. 481

${ }^{26}$ Tamże, s. 498.

${ }^{27}$ B. Wel te, Wahrheit und Geschichtlichkeit, „Saeculum” 3:1952 s. 187.
} 
zostaje $\mathrm{z}$ sytuacjami działania i dialogu człowieka $\mathrm{z}$ historią. Schillebeeckx uważa, że prawdy historycznej należy szukać w spotkaniach człowieka z historią oraz w każdorazowym akcie pośredniczenia przeszłości przez teraźniejszość. „W horyzoncie rozumienia ujmujemy siebie samych i wszystkich innych i to zarówno w teraźniejszości jak i przeszłości"28.

Przynależność człowieka do historii stwarza specyficzną sytuację dla poszukiwania przezeń prawdy tej historii. „Jako rozumiejący zostaliśmy wpisani w wydarzenie historii, ale przychodzimy za późno, jeżeli chcemy wiedzieć to, co powinniśmy rozumieć" - mówi Schultz ${ }^{29}$. Zadaniem hermeneutyki historii jest nie tyle określić i zrozumieć miejsce człowieka w historii, ile ustalić miejsce prawdy, które wyznaczone jest przez dialog teraźniejszości z przyszłością, jaki prowadzi człowiek. Okazuje się, że najpewniejszym fundamentem prawdy, jest byt ludzki. Prawda bycia człowieka sprowadza się ostatecznie do bycia wolnym. To wolność stanowi warunek ujęcia prawdy rozumienia historycznego. W efekcie można mówić o uprzywilejowanym miejscu bytu ludzkiego w odkrywaniu prawdy. Znaczącą rolę odgrywa tu egzystencja, która stanowi podstawę sensu, tym samym staje się czynnikiem konstytuującym prawdę bycia. Innym ważnym elementem jest zdolność transcendencji bytu ludzkiego w kierunku wszelkiej prawdy obiektywnej, co decyduje o tym, że prawda hermeneutyczna historii nie zostaje sprowadzona do wymiaru czysto podmiotowego.

Hermeneutyka transcendentalna stoi na stanowisku, że tylko prawda rozumiana jako akt bycia (Seinsakt) może stanowić prawdę naszego poznania i jako taka może być prawdą absolutną. To, co jest w każdym aspekcie oczywiste i jako takie istnieje, musi być również prawdziwe. Prawda absolutna jest nam dana w aktach istotowych naszego umysłu. Tylko w tym sensie możemy mówić, że prawda naszego umysłu, poznania i rozumienia posiada charakter niezmienności i wieczności. Każde odniesienie tej prawdy do konkretnych modyfikacji sprawia, że staje się prawdą o charakterze czysto podmiotowym.

Refleksja poznania prowadzi nas na teren prawdy, która jak mówi Welte „należy do pierwotnej istoty ludzkiego bytu" 30 . Uzasadnieniem dla tej prawdy jest nieograniczoność horyzontu komunikowania się człowieka, w ramach którego każdy dialog staje się możliwym. Tym samym prawda naszego rozumienia, jako prawda rzeczywistości udziela się podmiotowi poznającemu. Nie ulega wątpliwości, że sprowadzenie prawdy do podstawowego aktu bycia jest równocześnie nadaniem jej charakteru apriorycznego. Mimo to prawda naszego poznania jest każdorazowo urzeczywistniana i dzięki temu mogę o niej powiedzieć, że jest „moją prawdą”. Nie chodzi o jej czysto subiektywistyczny cha-

${ }^{28}$ E. Schille beeckx, Auf dem Weg zu einer katholischen Anwendung der Hermeneutik, [w:] Neue Perspektiven, Wien 1968, s. 98.

${ }^{29}$ Por. W. S chult z, Anmerkungen zur Hermeneutik Gadamers, [w:] Hermeneutik und Dialektik, Tübingen 1970, s. 314.

${ }^{30}$ B. Welt e, jw., s. 181. 
rakter, bo chociaż podmiot jest „nosicielem” prawdy, to jednak odnosi się ona do poznawanej rzeczy i w akcie komunikacji dokonuje się ciągłe jej urzeczywistnianie $^{31}$.

Prawda historyczna jest zawsze ujednostkowiona i jako taka doświadczana jest w jednostkowych aktach rozumienia. Wiadomo już, że każde rozumienie jednostkowe prowadzi nas do doświadczenia i rozumienia tego, co całościowe. Taka również droga prowadzi nas do poznania prawdy całościowej i absolutnej. Człowiek pozostając częścią horyzontu prawdy historycznej, nie jest zdolny ująć prawdy w jej wymiarze absolutnym. Każdorazowo musi prawdę absolutną suponować, jako warunek każdej prawdy historycznej ${ }^{32}$. Doświadczenie i rozumienie sensu poszczególnych faktów historii jest równocześnie źródłem jednostkowej i podmiotowej prawdy naszego rozumienia historycznego. Prawdę naszego rozumienia musimy ustawicznie konfrontować z prawdą powszechnego rozumienia, ażeby możliwym był nasz dialog z przeszłością. Lotz, kiedy mówi o prawdzie rozumienia historycznego, mówi zawsze o prawdzie in concreto, ale tym samym zakłada i odnosi ją do prawdy in abstracto, która jest fundamentem i podstawą odniesienia wszelkich prawd jednostkowych. Językowe teksty historyczne przekazują nam prawdę w jej wielorakich uwarunkowaniach, co decyduje o tym, że prawda rozumienia historycznego posiada charakter subiektywny. Nie należy jednak zapominać o tym, że mamy do czynienia z prawdą rozumienia historycznego, które charakteryzuje się dynamiką i jest procesem zmierzającym ku pełni sensu i pełni prawdy. Tym samym wkraczamy na drogą prowadzącą ku obiektywizmowi prawdy naszego rozumienia historycznego.

\section{Obiektywny charakter prawdy historycznej}

Możliwość dojścia do prawdy obiektywnej prowadzi nas przez obiektywizm poznania i rozumienia historycznego. Możemy mówić o przezwyciężeniu subiektywizmu poznawczego, jeżeli dojdzie się do obiektywnej prawdy, która byłaby absolutnie ważną dla wszystkich.

\section{Możliwości przezwyciężenia subiektywizmu}

Można dostrzec istotną zbieżność i zgodność stanowisk hermeneutyki egzystencjalnej i transcendentalnej, iż „nie ma w ogóle takich fenomenów historii, które mogłyby zaistnieć bez podmiotu obecnego w historii" ${ }^{33}$. Chodzi oczywiś-

31 Tamże, s. 190.

32 Por. tamże, s. 184

${ }^{33}$ E. B t t i, Die Hermeneutik als allgemeine Methodik der Geistwissenschaften, Tübingen 1962 , s. 22. 
cie o fakty i wydarzenia należące do historii, z którymi jednak podmíot pozostaje związany horyzontem swej egzystencji. Dzięki temu związkowi, fenomeny historii zyskują swoje znaczenie i możliwym staje się ujmowanie ich sensu. Natomiast fakty, które pozostają w bardzo luźnym związku z podmiotem, zyskują swoisty charakter historyczny przez stawianie „im” pytań. Skoro wszelka interpretacja i rozumienie tekstu historycznego możliwe jest w odniesieniu do podmiotu, to w konsekwencji, jak mówi Bultmann, najbardziej subiektywistyczna interpretacja historii jest zarazem najbardziej obiektywistyczną. Subiektywizm w odniesieniu do prawdy historycznej, może być wynikiem przesunięcia sensu, a więc jako rezultat złej perspektywy poznawczej historyka. Tak więc nieuwzględnianie postulatów samego tekstu, gdy chodzi o stawianie pytań, aspektowość w ujmowaniu sensu, to najczęstsze powody zatracenia obiektywizmu prawdy, co nie stanowi jeszcze o jej subiektywizmie a w każdym razie nie uprawnia do eliminowania $\mathrm{z}$ interpretacji historycznych obiektywności ${ }^{34}$. Jeszcze innym niebezpieczeństwem odejścia od obiektywizmu rozumienia i jego prawdy jest tzw. „egzystancjalne spotkanie z historią”. Wynikiem takiego spotkania jest najczęściej przesunięcie sensu, jako rezultat zmieniających się uwarunkowań poznawczych podmiotu i zmian znaczeniowych samych fenomenów historycznych, które mają miejsce w różnych epokach.

Możliwością przezwyciężania subiektywizmu rozumienia i prawdy historycznej jest dojście do takich założeń podmiotowych, które stanowiłyby kryterium w odniesieniu do każdego fenomenu historii i to, bez względu na czas i okoliczności. Chodzi w pierwszym rzędzie o takie założenia aprioryczne, które wzorem dogmatyki Kantowskiej stanowiłyby krytykę „rozumu historycznego”. Poza tym należy uznać, że każda kategoria przeżyciowa stanowi cząstkę, która jest elementem uzasadniającym rozumienie historii. Każde przeżycie podmiotowe jest bezpośrednim i całościowym doświadczeniem sensu historii. Według Diltheya w przezwyciężaniu subiektywizmu prawdy rozumienia historycznego istotną rolę może odgrywać również aspekt biograficzny. Chodzi w nim o powiązanie ze światem duchowym tych faktów, które w poznaniu ujmuje człowiek ${ }^{35}$. W wyniku podmiotowego nastawienia do sensu historii dokonuje się tym samym proces tworzenia obiektywnej wiedzy. W przypadku historii uniwersalnej i jej obiektywnej prawdy zachodzi konieczność redukowania prymatu podmiotu do relacji podmiotowo-przedmiotowych wyższego rzędu. Jeżeli przyjmie się kategorie najbardziej powszechne, wówczas rozumienie i jego prawda staje się nie tylko funkcją jednostki, ale całej ludzkości. Dilthey idąc po tej linii przyjął dwustopniową indywidualność, w której dokonuje się przejście od transcendentalno-hermeneutycznych założeń do krytycznej oceny

${ }^{34}$ S. O t to, Die Kritik der historischen Vernunft innerhalb der Denkfigur des hegelschen „Vernunftschlusses”, „Philosophisches Jahrbuch der Görres-Gesellschaft” 1974 s. 30.

${ }^{35}$ Por. W. Dil th ey, jw., s. 191. 
historii i rozumienia obecnej w niej podmiotowości. Otto natomiast zwraca uwagę na ponadjednostkowe podejście do historii oraz ujęcie ontologicznego wymiaru w stosunkach podmiotu do historii. Ponadto tenże wymiar ontologiczny pozwala ująć transcendentalną historyczność. Nie ulega wątpliwości, że problem subiektywizmu w rozumieniu historycznym i w jego prawdzie stanowi nadal we wszystkich rodzajach hermeneutyki punkt newralgiczny. Zdaniem Otta „tylko na fundamencie ontologicznie zorientowanej antropologii filozoficznej można oprzeć i uzasadnić całą „krytykę rozumu historycznego"36. Refleksja transcendentalna umożliwia przeniesienie refleksji podmiotowej na wyższy poziom urzeczywistnienia, co w odniesieniu do rozumienia i jego prawdy, stanowi istotne kryterium. Natomiast Maréchal opowiada się za koniecznością przeprowadzenia swoistej „syntezy dynamicznej”, która poprzedzałaby prawdę rozumienia historycznego. W wyniku tej syntezy kategorialnej, prawda rozumienia historycznego nie ograniczałaby się do ujmowania czegoś w świadomości, ale byłaby dynamicznym odniesieniem ${ }^{37}$.

Inną możliwością przezwyciężenia subiektywizmu jest dokonanie porównawczego ujęcia czasowości, w wyniku czego, czasowość rozumienia zostaje sprowadzona do transcendentalnej ogólności, w horyzoncie której zrozumiałymi stają się poszczególne fakty historyczne. Wszystkie te tendencje uwzględniają fakt, iż historia jest wydarzeniem wewnątrzświatowym i jako taka pozostaje stale w horyzoncie dokonujących się zmian i dlatego też nie można jej sprowadzać do czysto podmiotowych zmian myślenia i wartościowania.

Konkludując nasze rozważania możemy stwierdzić, iż istota historii uzależniona jest od immanencji i transcendencji ducha ludzkiego. Ujmowanie historii i jej prawdy w powiązaniu $\mathrm{z}$ transcendencją ducha ludzkiego pozwala nam przezwyciężać zarówno konieczność jak determinizm historyczny, który widoczny jest w Heglowskiej wizji historii. W konsekwencji czlowiek wobec takiego rozumienia historii pozostaje tylko pasywnym obserwatorem, który sam podlega koniecznościowym przeznaczeniom. Natomiast transcendencja poznania ludzkiego stanowi nieodzowny warunek obiektywnego rozumienia historii. Obiektywizm rozumienia z kolei prowadzi nas obiektywnej prawdy, która byłaby absolutnie ważna i prowadziłaby do pełnej wolności człowieka.

${ }^{36}$ S. Otto, jw., s. 30

37 J. Maréch al, Le point de départ de la Metaphysique, Paris 1964, s. 396. 


\section{ERMENEUTICA DELLA STORIA \\ NELL'ASPETTO DELLA VERITA DI COMPRENSIONE}

\section{Riassunto}

L'ermeneutica della storia nell'aspetto della verità di comprensione. La dimensione specifica della conoscenza umana basata sulla comprensione della storia. Sarebbe ridotta la semplice comprensione del senso senza considerare il carattere dinamico della storia. L'ermeneutica prende in considerazione l'aspetto della continua creatività e trasformazione delle forme di comprensione storica, accompagnata della consapevolezza della comprensione soggettiva. Il problema della storia e della sua comprensione appare nelle principali correnti dell'ermeneutica contemporanea che mira alla più profonda comprensione del senso il quale conduce all'universalismo obiettivo della storia. La corrente esistenziale e fenomenologica e la corrente dell'ermeneutica transcendentale considera la st o r i c i à come l'orizzonte indispensabile della comprensione. La distanza nel tempo permette all'uomo „esserein-storia” per cui si compie, ogni volta, l'unione di un fenomeno personale con l'esperienza storica del senso. Il posto centrale dell'uomo nella comprensione della storia è definito, tra l'altro, dalla possibilità di porre alla storia delle nuove domande e dalla possibilità di dare delle nuove, sempre più esaurienti, risposte.

La verità de comprensione-definisce all'ermeneutica la direzione dell'esplorazione e della ricerca delle soluzioni. La verità storica occupa il suo posto unico e irrefutabile nell'atto di comprensione. Secondo Heidegger la verità storica è soprattutto „l'avvenimento d'essere”, invece Welte e gli altri transcendentalisti mettono l'accento sul duplice aspetto della verità: sull'aspetto individuale e sull'aspetto assoluto. Nella comprensione ermeneutica della storia si considera soprattutto la verità obiettiva per evitare il soggetivismo. Si tratta di un processo di transcendentizzazione della verità dai fatti storici alla ,sintesi dinamica”, di passare dall'immanenza della verità di comprensione alla trascendenza dello spirito umano. L'elemento essenziale della verità di comprensione della storia è il concetto d'essere umano, da cui dipende sia la comprensione, sia la sua verità. 